\title{
The Development and Validation of the Teacher \\ Violence Scale
}

\author{
Metin PIŞKIN* \\ Gökhan ATIK* \\ Şakir ÇINKIR ${ }^{* * *}$ \\ Selahiddin ÖĞÜLMÜŞ \\ Cem BABADOĞAN ${ }^{*+\alpha+k x}$ \\ Ömay ÇOKLUK
}

\section{Suggested Citation:}

Pişkin, M., Atik, G., Çınkır, Ş., Öğülmüş, S., Babadoğan, C., \& Çokluk, Ö. (2014). The development and validation of Teacher Violence Scale. Eurasian Journal of Educational Research, 56, 1-24

\begin{abstract}
Problem Statement: One of the initial tasks of the school staff is to create a safe environment, which is free of negative behaviors and role models. However, there has been a concern for the violence in the schools. Most of studies in the literature has focused on aggression, violence, and bullying among students. But, teacher violence against students hasn't been studied sufficiently. In order to investigate this type of violence, a self-report instrument is needed.
\end{abstract}

\footnotetext{
* Dr. Ankara University, Faculty of Educational Sciences, Ankara, Turkey. E-mail: metinpiskin@gmail.com

** Corresponding author: Dr. Ankara University, Faculty of Educational Sciences,. Ankara, 06590, Turkey, Phone: +903123633350. E-mail: gokhanatik@gmail.com

*** Dr. Ankara University, Faculty of Educational Sciences, Ankara, Turkey. E-mail: cinkir@gmail.com

Dr. Ankara University, Faculty of Educational Sciences, Ankara, Turkey. E-mail: ogulmus@ankara.edu.tr

Dr. Ankara University, Faculty of Educational Sciences, Ankara, Turkey. E-mail: cem@babadogan.net

Dr. Ankara University, Faculty of Educational Sciences, Ankara, Turkey. E-mail: cokluk@education.ankara.edu.tr
} 
Purpose of the Study: This study aimed to develop and validate the Teacher Violence Scale (TVS), which measures different forms of violent behaviors displayed by teachers against students.

Method: The psychometric properties of the TVS were explored on two separate participant groups. The first one was consisted of $583(61.0 \%$ girls and $39.0 \%$ boys) high school students. The second one was composed of 878 (36.7\% girls and $63.3 \%$ boys) high school students. The initial phases of scale development started with defining the target construct, generating items, and receiving expert reviews. The pilot form was administered to the first participant group and the final form was validated on the second participant group. In addition, some evidence for convergent, discriminant and divergent validity of the TVS were explored. Lastly, the internal consistency for the entire scale and the sub-dimensions of the TVS and the item analysis of the TVS were investigated.

Findings and Results: The exploratory factor analysis (EFA) indicated that the TVS is a 36-item scale with 5 factors namely physical violence (11 items), sexual violence (6 items), accusing/humiliating (8 items), taunting (5 items), and oppressing (6 items). This 5-factor structure explained approximately 64 percent of the total variance. The confirmatory factor analysis (CFA) showed that the 5-factor model was validated $\left[\chi^{2}(584)=1330.27, \chi^{2} / d f=2.28, R M S E A=.04, S R M R=.06\right.$, $N N F I=.99, C F I=.99]$. The TVS had a strong evidence for convergent, discriminant and divergent validity. In addition, it had good internal consistency for the scores of entire scale and sub-dimensions.

Conclusion and Recommendations: This study presented some psychometric evidence for the TVS. The results of EFA and CFA indicated that the TVS is a 36-item scale with 5 sub-dimensions. It is expected that the TVS will fill a gap and will be a useful instrument to measure teachers' violence towards students. Further studies should provide additional evidence for predictive and cross validity and testretest reliability of the TVS.

Keywords: Teacher violence, scale development, validity, reliability, high school students

\section{Introduction}

Although violence is an enduring problem in societies for centuries, it hasn't been considered as a serious problem for a long time (Pişkin, 2006a). Today, it is apparent that there has been a growing awareness on school violence in Turkey and mass media has given more attention to this issue (Pişkin, Çınkır et al., 2011; Pişkin et al., 2011). However, one of the important responsibilities of schools is to provide an environment that is free of unacceptable behaviors and role models. Moreover, to 
feel secure and safe are the prerequisites for keeping on educational activities in schools (Öğülmüş, 1995).

Violence has detrimental effects on children's development. Although there has been more emphasis on physical harms of violence on students, it also leads to a set of psychological problems such as stress and anxiety. Support to this argument is provided by the observation that students who witnessed violence were psychologically influenced (Furlong \& Morrison, 1994). Janosz et al. (2008) pointed out that witnessing violence in schools has a deleterious impact on students' wellbeing and it is associated with feelings of insecurity, internalizing problems, later school engagement, poor academic achievement, and truancy. In addition, violence slows down academic, physical, and social development of students and hinders them to achieve their maximum capacity (Furlong, Morrison, \& Clontz, 1993). Studies carried out on Turkish elementary and high school samples indicated that most of victimized students felt to be less attracted to their schools and were afraid to go their schools because of bullies (Pişkin, 2010; Pişkin \& Ayas, 2005). However, in schools, all students have to be protected from the factors that could be a threat to their physical and psychological well-being. To feel secure and safe is very crucial not only for students but also for all people having a role in schools and education.

Many countries have paid an increased attention to and had concerns about school violence and school safety (Chen \& Astor, 2010; Conoley \& Goldstein, 2004; Due, Holstein, \& Soc, 2008; Nansel et al., 2001; Pişkin, Öğülmüş et al., 2011). When the relevant literature was investigated, it was understood that great attention has been paid to the violent behaviors among students. Students are the focus of research studies. However, to believe that school violence or school safety is related only with incidents among students could be misleading. It is necessary to consider violent behaviors displayed by teachers toward students as well. In the literature, there is a paucity of research investigating violent behaviors of teachers towards students as compared to studies of violence among students. The scant interest of researchers about teacher violent behaviors may have several reasons. First, since teachers are perceived as an authoritative figure in most cultures, to question their acts may not be culturally appropriate. Second, teachers' behaviors could be considered as a part of educational process and discipline. Therefore, most of their behaviors, including aggressive content could be seen as a way of education that again may prevent to question teachers' approaches. Lastly, the absence of scales evaluating teachers' behaviors could be another reason. A few available studies on violent behaviors displayed by teachers against students were conducted based on surveys or interviews.

\section{Definition of Teacher Violence}

Violence is a broad term and could be defined in many possible ways. But, as a global consensus, the World Health Organization (WHO) defines violence as "the intentional use of physical force or power, threatened or actual, against oneself, another person, or against a group or community, that either results in or has a high likelihood of resulting in injury, death, psychological harm, maldevelopment or 
deprivation" (WHO, 1996; as cited in WHO, 2002, p. 4). In accordance with this definition, we conceptualized teacher violence as the intentional use of power by teachers against students in different forms such as physical, verbal, psychological, and sexual, which aims to give harm.

\section{Research on Teachers' Violent Behaviors Against Students}

There is a paucity of research investigating violent behaviors towards students by teachers in Turkey when it is compared to studies of violence among students. Limited number of studies indicated that the most common violent behavior displayed by teachers toward students is corporal punishment (Gözütok, 1993b; Gözütok, Er, \& Karacaoğlu, 2006). It seems that corporal punishment has been used as part of education for years and seen as a manifestation of authority (Sümer \& Aydin, 1999). Culture has profound influences on the perception of violent behaviors. Studies pointed out that teachers and students believed that corporal punishment is a normal and an acceptable act in education (Saruhan, 1987; Timuroğlu, 1983). Sümer and Aydın (1999) noted that most of the teachers believed that corporal punishment isn't an effective method of discipline and they are looking for new strategies in dealing with students' problem behaviors in schools. Studies on corporal punishment in Turkish schools can be summarized with several themes, namely punishment strategies used by teachers, role of teachers' gender, and places where those punishments or violent behaviors happened. For the first one, Gözütok (1993a) examined the behaviors of teachers in maintaining discipline and found that 30 percent of the teachers were using negative discipline strategies such as slapping, ear and hair pulling, insulting, threatening etc. In another study, Gözütok et al. (2006) investigated students' perspectives with respect to punishment strategies applied by their teachers. Most of the students reported ears and hairs pulling, slapping, throwing chalk and eraser were the most prevalent punishment methods used by their teachers. Regarding the role of gender in teacher violence, studies found that male teachers were more likely to use negative discipline strategies or violent behaviors against students than female teachers did (Bulut, 2008; Gözütok, 1993a; Hatunoğlu \& Hatunoğlu, 2005). Finally, Bulut (2008) reported that these incidents mostly occurred in classrooms and principals' room.

It is obvious that corporal or physical punishment and school violence have a causal relationship that the use of physical punishment increases the probability of violence in schools (Straus, 1991). Since children whom does their teacher punish or parents have a perception of "being bad", they can continue their misbehaviors. Ada (2010) found that students punished as a procedure of school discipline are more likely to involve in bullying. Straus (1991) also points out that this causal relationship continues in future and increases the likelihood of deviance such as delinquency, crime, wife-beating etc. Ünal and Çukur (2011) explored the association between delinquency and school related factors, such as attachment to teacher, commitment to school, and discipline techniques. They found that delinquency was negatively related to attachment to teacher, commitment to school, and inductive discipline techniques. In addition, they reported that delinquency was positively associated with coercive discipline techniques and being bullied in school. 
Teachers' behaviors are seen as a role modeling and their positive behaviors will contribute significantly to the development of children. A study (Telli, den Brok, \& Çakıroğlu, 2008) investigating perceptions of students regarding the concept of ideal teacher found that students described the ideal teacher as a person who is guiding, motivating, encouraging, respecting, and instilling confidence and has a potential to build positive relationship with others. Therefore, having healthy communication with students will provide a motivation for students how to direct their lives in a more positive way. Yurtal and Artut (2010) suggested that the approaches of teachers and principal for dealing with problems are very crucial. If they use violence coping with problems, this may increase the inclination toward it. The aggressive teacher and principal figures in children's drawings are also good evidence for how teachers and principals have an influential role in students' world (Yurtal \& Artut, 2010). In a qualitative study, Çakmak (2011) investigated the perspectives of 185 Turkish prospective teachers related to changing roles of teachers. Interestingly, majority of the prospective teachers reported that their primary roles as a teacher were to transmit knowledge, guide, and to deliver the content in the program. Being a role model was reported at the eleveth place. This finding indicated that the prospective teachers prioritized the tasks related to their self-improvements more than other roles.

\title{
Purpose of the Study
}

Considering the lack of instruments in the literature, it is obvious that there is a need to develop a scale evaluating the multidimensional nature of teacher violence. It is expected that such a tool could promote research that will contribute to understanding the nature of behaviors displayed by teachers against students. Therefore, the present study aimed at developing a valid and reliable instrument to assess violent behaviors of teachers towards students in schools.

\begin{abstract}
Method
Participants

Two groups of participants were used in this study to perform exploratory and confirmatory factor analyses. Exploratory factor analysis was done on the first participant group that consisted of 583 students from five different types of high schools located in urban and rural areas of Ankara, Turkey. The selection of schools was done purposively considering the variation in types of high schools in Turkey. These school types were General, Anatolian, Girls' Vocational, Industrial Vocational, and Imam-Preacher high schools. The participants were selected through employing a convenience sampling. Two hundred twenty two (39.0\%) of the participants were boys and $351(61.0 \%)$ of them were girls. This group consisted of $146(25.5 \%)$ ninth, $172(29.9 \%)$ tenth, 146 (25.5\%) eleventh, and 110 (19.1\%) twelfth grade students.
\end{abstract}

Confirmatory factor analysis was done on the second participant group that comprised of 878 high school students. This group was drawn from four high schools in Ankara. Three hundred three participants (36.7\%) were girls and $522(63.3 \%)$ were 
boys. Fifty-three participants didn't report their gender information. The study group consisted of $252(32.5 \%)$ ninth, $188(24.2 \%)$ tenth, 175 (22.6\%) eleventh, and 161 $(20.7 \%)$ twelfth grade students. A hundred two participants didn't report their grade level information. The participants' age ranged from 14 to $20(M=16.42, S D=1.21)$.

\section{Measures}

Demographic variables. The participants completed a demographic information form including questions about gender, grade level, age, and type of school.

Teacher violence against students. Teacher Violence Scale (TVS) (see Appendix I) evaluates the violent behaviors displayed by teachers against students. This is a student self-report and measures teachers' violent behaviors from the perspective of students. The TVS which is a 36-item scale was responded on a 6-point scale ranging from $0=$ never to $5=$ almost every day. Higher scores obtained from the scale indicated higher teacher violence toward students.

Perceptions about bullying. The Myths about Bullying Inventory (MABI) developed by Pişkin (2006b) was administered to measure students' prejudgments, irrational beliefs and thoughts about bullying. The MABI is a $27-i$ tem scale with five response options ranging from $1=$ strongly disagree to $5=$ strongly agree. The scale consists of two dimensions namely erroneous approaches in dealing with bullying and justification of bullying behaviors. The Cronbach's alpha coefficients were found as .89 for the entire scale, .82 for the first dimension, and .83 for the second dimension. In the current study, this instrument was used as a criterion for the divergent validity of TVS.

\section{Procedure}

Item development. During the process of scale development, the researchers conducted a comprehensive literature review and interviews with students, teachers, and school principals by asking their opinions about teachers' violent behaviors towards students. The researchers generated items based on the literature review and opinions of these groups. These generated items were examined in terms of clarity and content appropriateness by a group of faculty members from the departments of psychological counseling and guidance, educational psychology, curriculum development, educational administration and policy, and measurement and evaluation. This process was finalized with a pilot form including 43 items.

Data collection process. This study was carried out during the spring semester of 2009/2010 academic year. Prior to scale administration, the approval was received from the Turkish Ministry of National Education. Then, the researchers visited the high schools located in rural and urban area of Ankara to explain the purpose of the study. After obtaining schools' approval, the data were collected through collaborating with school counselors and teachers. The instruments were administered in the classrooms by the researchers and the instruction about how to respond to the scales and the purpose of the study were provided to the participants. During the data collection process, some ethical issues such as informed consent, 
confidentiality, and volunteered participation were also ensured. Administration lasted about twenty-five minutes.

\section{Analysis of Data}

To reveal the underlying structure among the items in the TVS, an exploratory factor analysis (EFA) was conducted. Then, the factor structure obtained with the EFA was tested with confirmatory factor analysis (CFA) to test whether this structure was consistent with the data. After confirming the factor structure of the TVS, more evidence for the validity of the TVS (e.g. convergent, discriminant and divergent validity) was explored. Lastly, the internal consistencies for overall and subdimensions scores of the TVS were calculated and the item analysis was performed.

\section{Results}

\section{Exploratory Factor Analysis (EFA)}

An EFA using maximum likelihood extraction with an oblique rotation was performed to explore the TVS's underlying factor structure. The rationale of an oblique rotation is that it assumes correlations between the factors (Tabachnick \& Fidell, 2001). Supporting this, high correlations between the factors were found. Kaiser-Meyer-Olkin Measure of Sampling Adequacy indicated that the sample size of the study was quite appropriate for the factor analysis (.95), which should be greater than .60 (Tabachnick \& Fidell, 2001) to conduct a factor analysis. Bartlett's Test of Sphericity was also significant. The EFA using maximum likelihood method with an oblique rotation revealed a six-factor solution with eigenvalues over one. Eigenvalues of these components were 40.97, 7.65, 6.23, 3.20, 2.99, and 2.62, respectively. This six-factor solution explained 63.66 percent of the total variance. Since the six-factor solution wasn't interpretable, we identified a five-factor solution considering our pre-determined number of factors based on the research objectives. Therefore, we repeated the EFA with fixing the number of factors at five. The selection of items were performed based on eigenvalues (>1), factor loading $(>.32)$, and cross-loadings on other dimensions (Tabachnick \& Fidell, 2001). Seven items were cross-loaded on other components and omitted from the scale. After that, the EFA was repeated on the remaining 36 items. This five-factor solution was interpretable and met the item selection criteria (e.g., factor loadings above .32). A five-factor solution accounted for 63.81 percent of the total variance. Factors, items, factors loadings, means, and standard deviations were presented in Table 1 . The first factor was labeled as physical violence and consisted of 11 items accounting for 41.31 percent of the total variance. The second factor was labeled as sexual violence, included 6 items and accounted for 8.41 percent of the total variance. The third factor was labeled as accusing/humiliating, included 8 items and accounted for 7.20 percent of the total variance. The fourth factor was labeled as taunting, consisted of 5 items and accounted for 3.60 percent of the total variance. Lastly, the fifth factor was labeled as oppressing, included 6 items and accounted for 3.29 percent of the total variance. 
Table 1.

Items, Factor Loadings, and Descriptive Statistics for the TVS

\begin{tabular}{|c|c|c|c|c|c|c|c|}
\hline \multirow[b]{2}{*}{36 items } & \multicolumn{5}{|c|}{ Factor Loadings } & \multirow[b]{2}{*}{$M$} & \multirow[b]{2}{*}{$S D$} \\
\hline & $\mathrm{F} 1$ & F2 & F3 & F4 & F5 & & \\
\hline \multicolumn{8}{|l|}{ Physical Violence } \\
\hline 3. Slapping on the face & .88 & .02 & .01 & -.12 & -.00 & .51 & 1.16 \\
\hline 5. Hitting on the head & .81 & -.02 & .03 & -.04 & -.04 & .51 & 1.21 \\
\hline $\begin{array}{l}\text { 9. Hitting with an object such as stick, ruler } \\
\text { etc. }\end{array}$ & .74 & .04 & .06 & -.00 & .05 & .57 & 1.23 \\
\hline 2. Pulling ears & .71 & .01 & .02 & -.04 & .13 & .40 & 1.00 \\
\hline 4. Punching & .69 & -.13 & -.02 & .08 & -.15 & .36 & 1.06 \\
\hline 8. Kicking & .65 & -.06 & -.03 & .12 & -.08 & .35 & 1.01 \\
\hline 6. Clinking heads of two students & .64 & -.18 & .04 & .06 & -.12 & .35 & 1.04 \\
\hline 10. Throwing some objects to students & .61 & .05 & .07 & .14 & .12 & .60 & 1.27 \\
\hline $\begin{array}{l}\text { 7. Hitting the head of the students against } \\
\text { the wall or desk }\end{array}$ & .56 & -.03 & -.02 & .15 & .06 & .23 & .85 \\
\hline 1. Pulling hair & .44 & .04 & .07 & .10 & .11 & .31 & .93 \\
\hline $\begin{array}{l}\text { 11. Making student to stand on one foot in } \\
\text { the classroom }\end{array}$ & .39 & -.12 & -.05 & .23 & .17 & .40 & 1.08 \\
\hline \multicolumn{8}{|l|}{ Sexual Violence } \\
\hline $\begin{array}{l}\text { 41. Sexual movements (hand, arm, eye } \\
\text { movement etc.) }\end{array}$ & .03 & -.96 & .02 & -.07 & -.01 & .25 & .92 \\
\hline $\begin{array}{l}\text { 40. Calling him/her with words having } \\
\text { sexual connotations }\end{array}$ & .05 & -.92 & .01 & -.10 & .06 & .26 & .91 \\
\hline 42. Sexual touching & .09 & -.87 & -.01 & .06 & -.04 & .27 & .97 \\
\hline $\begin{array}{l}\text { 43. Creating and spreading rumors of } \\
\text { sexual nature }\end{array}$ & -.03 & -.83 & -.01 & .13 & -.02 & .25 & .97 \\
\hline 39. Forcing to talk about sexuality & .03 & -.79 & -.01 & .08 & .04 & .22 & .84 \\
\hline 38. Making jokes of sexual nature & -.01 & -.78 & .07 & -.03 & .07 & .30 & .97 \\
\hline \multicolumn{8}{|l|}{ Accusing/Humiliating } \\
\hline 21. Accusing with no reason & -.03 & -.12 & .78 & -.01 & -.04 & 1.00 & 1.57 \\
\hline 20. Continuously searching to find defects & .02 & -.04 & .77 & .00 & -.10 & 1.03 & 1.64 \\
\hline $\begin{array}{l}25 . \text { Threatening to give low marks or to fail } \\
\text { the class }\end{array}$ & .03 & .03 & .68 & -.18 & .22 & 1.48 & 1.79 \\
\hline $\begin{array}{l}\text { 17. Scolding the whole class or a group that } \\
\text { you are in }\end{array}$ & .05 & .13 & .66 & .03 & .01 & 1.61 & 1.85 \\
\hline $\begin{array}{l}\text { 18. Calling rude words (stupid, silly, idiot, } \\
\text { meek etc.) }\end{array}$ & .18 & -.01 & .63 & .03 & -.03 & 1.02 & 1.63 \\
\hline 22. To regard as inferior & -.06 & -.10 & .61 & .22 & -.03 & .60 & 1.31 \\
\hline 26. To embarrass in front of the other & .03 & .04 & .60 & .12 & .20 & 1.12 & 1.64 \\
\hline
\end{tabular}
students (making fun of homework or exam papers) 
Tablo 1. Continue..

29. Ignoring not giving permission to talk, $\quad \begin{array}{llllllll}.01 & -.14 & .50 & .10 & .06 & .75 & 1.44\end{array}$ not responding to questions etc.

Taunting

13. Making fun about personal appearance (clothes, glasses, etc.)

14. Making fun about accents, dialect or style of pronunciation

12. Making fun of physical characteristics such as height, weight, dentition, color of hair, color of skin etc.

16. Calling insulting names, nicknames

15. Making fun about first name or surname

Oppressing

32. Restrict freedom such as not allowing to go out the class during break times

34. Unjustly complaining to the $\quad \begin{array}{lllllllll} & .02 & -.20 & .13 & .12 & .47 & .51 & 1.22\end{array}$

administration

36. Tearing personal belongings such as books, notebooks, homework or drawings

27. Giving extra homework as punishment

33. Making negative speech or comments about some students to influence the others

$\begin{array}{rrrrrrr}.13 & .01 & .15 & .61 & .03 & .31 & .88 \\ .19 & .03 & -.04 & .60 & .17 & .29 & .86 \\ & & & & & & \\ .15 & -.07 & .15 & .56 & -.06 & .35 & .99 \\ & & & & & & \\ & & & & & & \\ -.00 & -.10 & .16 & .55 & -.04 & .38 & 1.07 \\ .14 & -.12 & -.03 & .54 & .06 & .29 & .87\end{array}$

\begin{tabular}{|c|c|c|}
\hline-.20 & & 32 \\
\hline
\end{tabular}

$\begin{array}{lllllll}.11 & -.04 & .30 & -.03 & .42 & .91 & 1.48\end{array}$

$\begin{array}{lllllll}-.04 & -.14 & .24 & .22 & .37 & .50 & 1.20\end{array}$

\begin{tabular}{lllllll}
.03 & -.21 & .01 & .18 & .36 & .35 & 1.03 \\
\hline
\end{tabular}

\section{Confirmatory Factor Analysis (CFA)}

To test how well the five-factor model fit, a CFA was conducted. The purpose of conducting the CFA is that it provides many analytic possibilities (e.g., assessment of method effects, investigation of the stability or invariance of the factor model over informants) that are not possible to obtain with EFA (Brown, 2006). A CFA was performed using maximum-likelihood estimation to test the fit of five-factor model to the data. Results of the CFA suggested that the fit indices of the five-factor model was very good $\left[\chi^{2}(584)=1330.27, \chi^{2} / d f=2.28, R M S E A=.04, S R M R=.06, N N F I=\right.$ $.99, C F I=.99]$. The CFA results for the five-factor model of TVS were shown in Figure 1. Factor pattern coefficients for the items of physical violence ranged from .57 to .78 , those for items of taunting from .71 to .83 , those for items of accusing/humiliating from .61 to .80 , those for items of oppressing from .63 to .81 , and those for items of sexual violence from .83 to .91 . $R^{2}$ for the items of physical violence ranged from .32 to .61 , those for the items of taunting from .50 to .68 , those for the items of accusing/humiliating from .37 to .64 , those for the items of oppressing from .40 to .66 , and those for the items of sexual violence from .68 to .82 . 


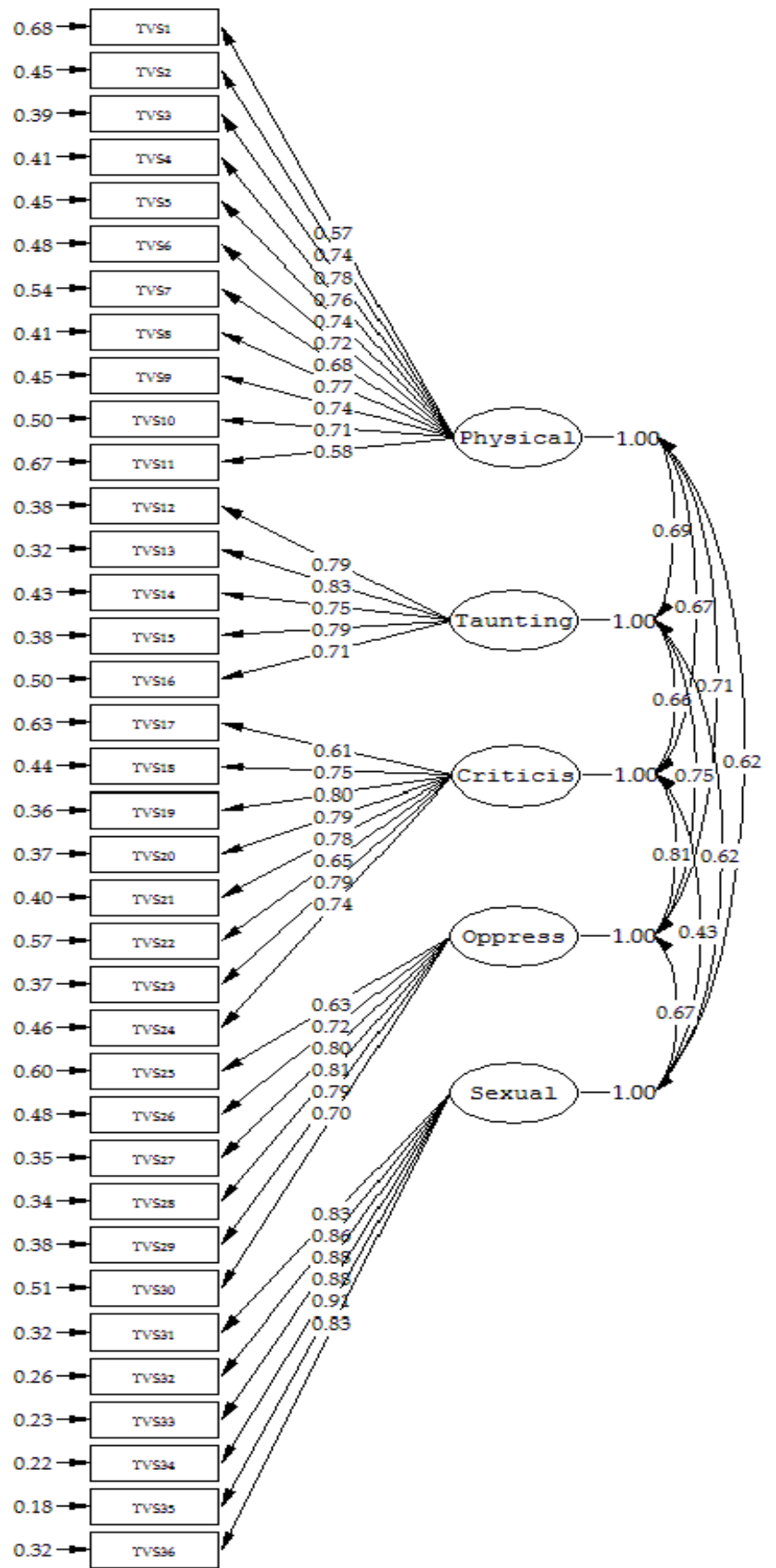

Figure 1. Confirmatory Factor Analysis of the Five-Factor Model of the TVS 
For the convergent validity of the TVS, standardized factor loadings of the items, average variance extracted (AVE) and composite reliabilities (CR) of the dimensions, and whether CR values are higher than AVE values were examined. Hair, Black, Babin, and Anderson (2010) suggested a criterion for the standardized factor loadings and AVE values as $\geq .50$ and a criterion for the $C R$ values as $\geq .70$. Byrne (2010) also suggested that the CR values should be larger than the AVE values. The results indicated that all standardized factor loadings and AVE values were above the criterion of $\geq .50$. Also, the composite reliabilities ranged between .80 and .94 , which they were above the criterion of $\geq .70$. Lastly, all CR values were larger than the AVE values of the dimensions of TVS. Consequently, these findings indicated a full evidence for the convergent validity of TVS.

For the discriminant validity of the TVS, maximum shared squared variances (MSV) and average shared squared variances (ASV) were explored. It is expected that the AVEs should be larger than MSVs and ASVs (Hair et al., 2010). All AVEs were larger than the ASVs. In addition, the AVEs of three dimensions (physical violence, taunting, and sexual violence) were larger than their MSVs whereas the AVEs of two dimensions (accusing/humiliating and oppressing) were smaller than their MSVs. These findings provided a partial support for the discriminant validity of the TVS.

\section{Divergent Validity of the TVS}

The study of divergent validity was conducted on the data of first participant group. Correlation findings (see Table 2) indicated that the total scores from each subscale and entire scale of the TVS were positively correlated to the total scores from each subscale of the MABI as well as to the MABI's total scores. Only one dimension of the TVS, accusing/humiliating, was unrelated to the second dimension of the MABI (Justification of Bullying Behaviors). Regarding divergent validity, the results indicated that these correlations were not too strong. This demonstrates that the construct of teacher violence is different from the construct of myths about bullying. 
Table 2.

Correlations, Reliabilities, Mean, and Standard Deviations for the Sub-dimensions and Total of TVS and $M A B I$

\begin{tabular}{|c|c|c|c|c|c|c|c|c|c|}
\hline Scales/Sub-dimensions & 1 & 2 & 3 & 4 & 5 & 6 & 7 & 8 & 9 \\
\hline 1. Physical Violence & - & & & & & & & & \\
\hline 2. Sexual Violence & $.56^{* *}$ & - & & & & & & & \\
\hline 3. Accusing/Humiliating & $.48^{* *}$ & $.41^{* *}$ & - & & & & & & \\
\hline 4. Taunting & $.69^{* *}$ & $.59^{* *}$ & $.53^{* *}$ & - & & & & & \\
\hline 5. Oppressing & $.61^{* *}$ & $.66^{* *}$ & $.64^{* *}$ & $.61^{* *}$ & - & & & & \\
\hline 6. TVS - Total & $.81^{* *}$ & $.74^{* *}$ & $.82^{* *}$ & $.79^{* *}$ & $.86^{* *}$ & - & & & \\
\hline 7. MABI - Subscale 1 & $.12^{* *}$ & $.15^{* *}$ & $.11^{*}$ & $.19^{* *}$ & $.22^{* *}$ & $.19^{* *}$ & - & & \\
\hline 8. MABI - Subscale 2 & $.18^{* *}$ & $.20^{* *}$ & .07 & $.24^{* *}$ & $.27^{* *}$ & $.21^{* *}$ & $.82^{* *}$ & - & \\
\hline 9. MABI - Total & $.17^{* *}$ & $.19^{* *}$ & $.09^{*}$ & $.22^{* *}$ & $.26^{* *}$ & $.21^{* *}$ & $.94^{* *}$ & $.96^{* *}$ & - \\
\hline$a$ & .93 & .96 & .89 & .85 & .85 & .96 & .90 & .92 & .95 \\
\hline$M$ & 4.57 & 1.54 & 8.37 & 1.61 & 3.23 & 23.756 & 27.59 & 30.62 & 58.05 \\
\hline$S D$ & 8.90 & 5.07 & 9.60 & 3.70 & 5.61 & 32.44 & 12.55 & 14.45 & 25.16 \\
\hline
\end{tabular}

Note. ${ }^{*} p<.05,{ }^{* *} p<.01$

\section{Internal Reliability of the TVS}

The Cronbach's alpha coefficients for the sub-dimensions and entire of the TVS were calculated using two participant groups. The coefficients obtained from the first participant group were presented in Table 2. These coefficients for the subdimensions of the TVS and for the entire scale ranged between .85 and 96 . The coefficients obtained from the second participant group were .92 for physical violence, .95 for sexual violence, .90 for accusing/humiliating, .88 for taunting, .87 for oppressing, and .96 for the entire scale. All these Cronbach's alpha coefficients indicated that the TVS had good internal consistencies.

\section{Item Analysis of the TVS}

The item analysis of the TVS was done using the data of second participant group. For the item analysis, the corrected-item total correlations and lower/upper $27 \%$ group differences for each item score were explored. The corrected-item total correlations for the TVS ranged between .50 and .70. The $t$-test results indicated significant group differences between lower $27 \%$ and upper $27 \%$ group of each item score $(p<.01)$. 


\section{Conclusions and Recommendations}

This study provides psychometric support for the Teacher Violence Scale (TVS). The EFA results indicated that the TVS yielded 5 distinguishable and interpretable factors including 36 items. These five factors explained almost 64 percent of the total variance. Factors were labeled as physical violence (11 items), sexual violence (6 items), accusing/humiliating (8 items), taunting (5 items), and oppressing (6 items). To validate the five-factor solution obtained through EFA, 36 items were analyzed with the CFA. Results of the CFA suggested a good fit to the data. The TVS had full evidence for the convergent validity and a partial evidence for discriminant validity. The results of divergent validity showed that greater exposure to the teacher violence was related to higher prejudgments, irrational beliefs and thoughts about bullying. However, there was no strong relationship between the scores of the TVS and the MABI. This indicates that the construct assessed by the TVS was different from the construct assessed by the MABI. The reliability estimates for the overall scale, as well as for the sub-dimensions of the TVS, suggested that it was a highly reliable instrument to use.

This study has provided some significant information to the field of teacher violence research. First of all, to the best of our knowledge, no instrument evaluating teacher violent behavior against students from the perspective of students has yet been developed. Therefore, it is expected that this scale will fill a gap and will be a useful tool for educators and researchers to evaluate teachers' aggressive behaviors towards students. An additional strength of this study is that the TVS was developed over a diverse population from different types of high schools and this enhances the applicability of our results to the schools and students displaying similar characteristics as the ones surveyed in Ankara.

The current investigation has several limitations. Firstly, the participants were selected from schools located only in Ankara. The generalizability of the TVS needs to be investigated among different populations and geographic locations. Secondly, this study only examined convergent, discriminant and divergent validity of the TVS. This needs to be expanded with additional validity studies, such as predictive, cross validity etc. Lastly, test-retest reliability coefficients weren't calculated due to a lack of repeated measures. Therefore, future studies should examine test-retest reliability of the TVS.

Acknowledgements: This study was supported by the Scientific and Technological Research Council of Turkey (TÜBİTAK) (Project No: 108K305; Project Title: "Determining Violence in High Schools and Developing a Prevention Program"). We acknowledged that some parts of this study was presented at the X. National Psychological Counseling and Guidance Congress (2009, October), in Adana. 


\section{References}

Ada, Ş. (2010). Analyzing peer bullying $6^{\text {th }}, 7^{\text {th }}$, and $8^{\text {th }}$ grades primary school students from the aspects of different variables in Erzurum. Education and Science, 35(158), 90-100.

Brown, T. A. (2006). Confirmatory factor analysis for applied research. New York: The Guilford Press.

Bulut, S. (2008). Öğretmenden öğrenciye yönelik olan fiziksel şiddet: Nicel bir araştırma [Violence that emerges from teachers toward students: A quantitative investigation]. Abant İzet Baysal Üniversitesi Eğitim Fakültesi Dergisi, 8(1), 105-118.

Byrne, B. M. (2010). Structural equation modeling with AMOS: Basic concepts, applications, and programming (2nd ed.). New York: Taylor \& Francis Group.

Chen, J. K., \& Astor, R. A. (2010). School violence in Taiwan: Examining how Western risk factors predict school violence in an Asian culture. Journal of Interpersonal Violence, 25(8), 1388-1410.

Conoley, J. C., \& Goldstein, A. P. (Eds.) (2004). School violence intervention: A practical handbook (2nd ed.). New York: Guilford.

Çakmak, M. (2011). Changing roles of teachers: Prospective teachers' thoughts. Education and Science, 36(159), 14-24.

Due, P., Holstein, B. E., \& Soc, M. S. (2008). Bullying victimization among 13 to 15year-old school children: Results from two comparative studies in 66 countries and regions. The International Journal of Adolescent Medicine and Health, 20(2), 209-221.

Furlong, M. J., \& Morrison, G. M. (1994). Addressing school violence as part of schools' educational mission. Preventing School Failure, 38(3), 10-17.

Furlong, M. J., Morrison, R., \& Clontz, D. (1993). Planning principles for safe schools. School Safety, Spring, 23-27.

Gözütok, F. D. (1993a). Disiplin sağlamada öğretmen davranışları [Teacher behaviour in maintaining discipline]. Ankara Üniversitesi Eğitim Bilimleri Fakültesi Dergisi, 25, 703-711.

Gözütok, F. D. (1993b). Okulda dayak [Beating students in schools]. Ankara: 72 Ofset.

Gözütok, F. D., Er, K. O., \& Karacaoğlu, Ö. C. (2006). Okulda dayak: 1992 ve 2006 yılları karşılaştırması [Beating in school: Comparing 1992 and 2006 years]. Toplumsal Bir Sorun Olarak Şiddet Sempozyumu [Violence as a Social Problem Symposium]. Retrieved March 09, 2011 http://ekutuphane.egitimsen.org.tr/pdf/1595.pdf

Hair, J. F., Black, W. C., Babin, B. J., \& Anderson, R. E. (2010). Multivariate data analysis: A global perspective (7th ed.). Upper Saddle River, NJ: Pearson. 
Hatunoğlu, B. Y., \& Hatunoğlu, A. (2005). Öğretmenlerin fiziksel cezalandırmaya ilişkin görüşleri [Opinions of teachers about physical punishment]. Atatürk Üniversitesi Sosyal Bilimler Enstitüsü Dergisi, 6(2), 105-115.

Janosz, M., Archambault, I., Pagani, L. S., Pascal, S., Morin, A. J. S., \& Bowen, F. (2008). Are there detrimental effects of witnessing school violence in early adolescence? Journal of Adolescent Health, 43, 600-608.

Nansel, T. R., Overpeck, M., Pilla, R. S., Ruan, W. J., Simons-Morton, B., \& Scheidt, P. (2001). Bullying behaviors among US youth: Prevalence and association with psychosocial adjustment. The Journal of the American Medical Association, 285(16), 2094-2100.

Öğ̈̈lmüş, S. (1995). Okullarda (liselerde) şiddet ve saldırganlık [Violence and aggresiveness in schools (in high schools)]. Unpublished report. Ankara University, Faculty of Educational Sciences, Ankara.

Pişkin, M. (2010). Examination of peer bullying among primary and middle school children in Ankara. Education and Science, 35(156), 175-189.

Pişkin, M. (2006a). Okul şiddeti: Tanımı, yaygınlığı ve önleme stratejileri [School violence: Definition, prevalence, and prevention strategies]. Kamuda Sosyal Politika, 1(2), 43-62.

Pişkin, M. (2006b). Validity and reliability of Myths About Bullying Inventory - MABI. Paper presented at the 10th EARA Conference (European Association for Research of Adolescence), Antalya, Sheraton Voyager Hotel.

Pişkin, M., \& Ayas, T. (2005, September). Lise öğrencileri arasında yaşanan akran zorbalığı olgusunun okul türü bakımından karşılaştırılması [A comparison of peer bullying among high school students with respect to school types]. Paper presented at the VIII. National Psychological Counseling and Guidance Congress, Marmara University, Istanbul.

Pişkin, M., Çınkır, Ş., Kalafat, T., Öğülmüss, S., Atik, G., Babadoğan, C., ... Şahan, B. (2011, October). Öğretmenlerin ve okul yöneticilerinin okul şiddetine ilişkin görüşleri [The perceptions of teachers and school principals related to school violence]. Paper presented at XI. National Psychological Counseling and Guidance Congress, Izmir, Turkey.

Pişkin, M., Öğülmüş, S., Atik, G., Çınkır, Ş., Çokluk, Ö., Babadoğan, C., ... Şahan, B. (2011, October). Liselerde öğrenciler arasındaki şiddetin saptanması [Determining school violence among high school students]. Paper presented at XI. National Psychological Counseling and Guidance Congress, Izmir, Turkey.

Saruhan, A. (1987). Bu çocuklar resmen dayak istiyor [These children actually deserve spanking]. Öğretmen Dünyast, 8(86), 22-24.

Straus, M. A. (1991). Discipline and deviance: Physical punishment of children and violence and other crime in adulthood. Social Problems, 38(2), 133-154. 
Sümer, Z. H., \& Aydın, G. (1999). Incidence of violence in Turkish schools: A review. International Journal for the Advancement of Counselling, 21, 335-347.

Tabachnick, B. G., \& Fidell, L. S. (2001). Using multivariate statistics (4 ed.). Boston: Allyn and Bacon.

Telli, S., den Brok, P., \& Çakıroğlu, J. (2008). Teachers' and students' perceptions of the ideal teacher. Education and Science, 33(149), 118-129.

Timuroğlu, V. (1983). Dayak ve demokratik eğitim [Corporal punishment and democratic education]. Öğretmen Dünyası, 4(39), 21.

Ünal, H., \& Çukur, C. Ş. (2011). The effects of school bonds, discipline techniques in school and victimization on delinquency of high school students. Educational Sciences: Theory \& Practice, 11(2), 560-570.

World Health Organization (WHO) (2002). World report on violence and health: Summary. Geneva.

Yurtal, F., \& Artut, K. (2010). An investigation of school violence through Turkish children's drawings. Journal of Interpersonal Violence, 25(1), 50-62.

\section{Öğretmen Şiddeti Ölçeği'nin Geliştirilmesi ve Doğrulanması}

Atıf:

Pişkin, M., Atik, G., Çınkır, Ş., Öğülmüş, S., Babadoğan, C., \& Çokluk, Ö. (2014). The development and validation of Teacher Violence Scale. Eurasian Journal of Educational Research, ..., ..., ...

\section{Özet}

Problem Durumu: Eğitimcilerin öncelikli görevleri arasında, olumsuz davranışların ve modellerin olmadığı güvenli bir eğitim ortamının oluşturulması yer almaktadır. Ancak, günümüzde okullarda yaşanan şiddet olaylarına yönelik bir endişe söz konusudur. Alan yazındaki ilgili çalışmalar incelendiğinde, araştırmalarda çoğunlukla öğrenciler arasındaki saldırganlık, şiddet ve zorbalık olaylarına odaklanıldığı, öğretmenden öğrenciye yönelik şiddet olaylarının yeteri kadar ele alınmadığı görülmektedir. Bu açıdan, okul şiddeti ya da okul güvenliği kapsamında sadece öğrencilerin uyguladıkları şiddet davranışları değil, öğretmenden öğrenciye yönelik şiddet davranışlarının da dikkate alınması gerekmektedir. Öğretmen şiddetiyle ilgili araştırmaların yetersiz olmasının birkaç faktörle ilişkili olduğu düşünülmektedir. Öncelikle, birçok kültürde, öğretmen otoriter bir figür olarak değerlendirilmekte ve öğretmenin davranışlarını sorgulamak kültürel açıdan uygun görülmemektedir. Diğer bir faktör ise, öğretmelerin öğrencilere yönelik birçok davranışı eğitim sürecinin ve disiplinin bir parçası olarak ele alınmaktadır. Son olarak, öğretmen davranışlarını değerlendirmeye yönelik ölçme araçlarının olmaması da, bu konunun yeteri kadar araştırılmasının önünde bir engel olarak düşünülebilir. 
Araştırmanın Amacı: Öğretmenden öğrenciye yönelik şiddet olaylarının araştırılabilmesi için öğrenciler tarafından yanıtlanabilecek bir ölçme aracına ihtiyaç duyulmaktadır. Bu çalışmada, okullarda öğretmenler tarafından öğrencilere uygulanan şiddet davranışlarını belirlemek için öğrenciler tarafından doldurulan bir ölçme aracının geliştirilmesi amaçlanmıştır.

Araştırmanın Yöntemi: Bu çalışmada iki farklı katılımcı grup verisi kullanılmıştır. Birinci katılımcı grup verileri üzerinde açımlayıcı faktör analizi, diğer grup verileri üzerinde ise doğrulayıcı faktör analizi yapılmıştır. Birinci katılımcı grup 583 (\%61.0 k1z, \%39.0 erkek), ikinci katılımcı grup ise 878 (\%36.7 kız, \%63.3 erkek) lise öğrencisinden oluşmuştur. Türkiye' deki lise türleri çeşitlilik göstermektedir. Bundan dolayı, araştırmaya katılan katılımcılar farklı lise türlerinden seçilmiştir. Bu okul türleri arasında; Genel, Anadolu, Kı Meslek, Endüstri Meslek ve İmam Hatip Liseleri yer almıştır. Ölçme aracının geliştirilmesi sürecinde, alan yazın gözden geçirilerek ve araştırmanın hedef grubunu oluşturan öğrenci, yönetici ve öğretmenlerin de görüşleri alınarak madde havuzu oluşturulmuştur. Oluşturulan maddeler psikolojik danışma ve rehberlik, eğitim psikolojisi, ölçme ve değerlendirme ve eğitim yönetimi alanlarında çalışan bir grup öğretim üyesinin görüşüne sunulmuş; ölçeğin deneme formu dil, ifade, içerik ve yapı bakımından incelenmiştir. Alınan geri bildirimler sonucunda, 43 maddelik ölçek, deneme uygulama için hazır hale getirilmiştir. Deneme uygulama birinci katılımcı grup verileri üzerinde yapılmıştır. Faktör analizi sonucunda, 43 maddelik deneme form 36 maddeye düşmüş ve 5 faktörlü bir yapı elde edilmiştir. Deneme uygulama sonucunda elde edilen bu yapının ikinci katılımcı grup verileri üzerinde geçerli olup olmadığı doğrulayıcı faktör analizi ile test edilmiştir. Geçerlik çalışması kapsamında ayrıca benzeme, ayırma ve ayrılma geçerlikleri de incelenmiştir. Son olarak, ölçeğin tamamı ve alt boyutları için iç-tutarlık güvenirlik katsayıları hesaplanmıştır.

Araştırmanın Bulguları: Açımlayıcı faktör analizi sonucunda, 43 maddelik deneme form 36 maddeye düşmüş ve 5 faktörlü bir yapı elde edilmiştir. Bu faktörler ve madde sayıları şöyledir: fiziksel şiddet (11 madde), cinsel şiddet (6 madde), suçlama/aşağılama (8 madde), alay etme (5 madde) ve baskı altına alma (6 madde). Beş faktörlü yapı toplam varyansın yaklaşık \% 64' ünü açıklamıştır. Doğrulayıcı faktör analizi sonuçlarına göre ise, elde edilen beş faktörlü yapı geçerli kılınmıştır [ $\chi^{2}(584)$ $\left.=1330.27, \chi^{2} / s d=2.28, R M S E A=.04, S R M R=.06, N N F I=.99, C F I=.99\right]$. Benzeme ve ayırma geçerlik çalışmalarının sonuçlarına göre, ölçek benzeme ve ayırma geçerliğine sahiptir. Ayrılma geçerliği sonucuna göre ise, ölçeğin puanları Zorbalığa İlişkin Mitler Ölçeği'nden elde edilen puanlarla manidar ve pozitif yönde ilişkili bulunmuştur. Ancak, elde edilen ilişkiler çok güçlü değildir. Bu açıdan, her iki ölçeğin ölçtüğü kavramlar birbirlerinden ayrışmaktadır. Ölçeğin iç-tutarlık güvenirlik katsayıları, Cronbach alfa katsayı ile hesaplanmıştır. Birinci ve ikinci katılımcı grupları için ölçeğin tamamına ilişkin Cronbach alfa değerleri $.96^{\prime}$ dır. Her iki katılımcı grup için, ölçeğin alt boyutları için elde edilen Cronbach alfa değerleri .85 ile .96 arasında değişmektedir.

Araştırmanın Sonuçları ve Öneriler: Bu çalışmada, Öğretmen Şiddeti Ölçeği'nin geliştirilmesi ve doğrulanması için birtakım psikometrik bulgular sunulmuştur. 
Açımlayıcı ve doğrulayıcı faktör analizleri sonucunda, ölçek 36 madde ve 5 alt boyuttan oluşmuştur. Benzeme, ayırma ve ayrılma geçerliğine ilişkin kanıtlar, ölçeğin yapı geçerliğine sahip olduğunu işaret etmektedir. Ölçeğin tamamı ve alt boyutları için elde edilen güvenirlik katsayıları, ölçeğin iyi bir iç-tutarlığa sahip olduğunu göstermektedir. İlgili alan yazında, öğrencilerin görüşlerine dayalı olarak, öğretmenlerin öğrencilere yönelik şiddet davranışlarını değerlendiren bir ölçek bulunmamaktadır. Bundan dolayı, bu ölçeğin öğretmen şiddeti ile ilgili alan yazına önemli bir katkı sağlayacağı düşünülmektedir. Ölçek farklı lise türlerine devam eden öğrenciler üzerinde uygulandığı için elde edilen sonuçların genellenebilirliği de söz konusu olabilir. Sonraki çalışmalarda, Öğretmen Şiddeti Ölçeği'nin geçerliğine (yordayıcı ve çapraz geçerlik gibi) ve güvenirliğine (test-tekrar test güvenirliği gibi) ilişkin ek kanıtlar araştırılabilir. Ayrıca, ölçeğin yapı geçerliği başka örneklemler üzerinde de incelenebilir.

Anahtar Sözcükler: Öğretmen şiddeti, ölçek geliştirme, geçerlik, güvenirlik, lise öğrencileri. 


\section{Appendix I}

\section{Teacher Violence Scale}

At below, there are some violent behaviors displayed by teachers against students. Please fill in the boxes for each item considering how frequently your teachers displayed these behaviors against you in the past year. Please respond to the items considering whether it happened to you and how frequently it happened. Considering the past year, fill in the boxes using a six-point scale given at below.

\section{Never}

2. At least once a year

3. At least once a term

4. At least once a month

5. At least once a week

6. Almost everyday

\begin{tabular}{|c|c|c|c|c|c|c|c|}
\hline & & 1 & 2 & 3 & 4 & 5 & 6 \\
\hline 1. & Pulling hair & 0 & 0 & 0 & o & 0 & 은 \\
\hline 2. & Pulling ears & 0 & 0 & 0 & 0 & 0 & 0 \\
\hline 3. & Slapping on the face & 0 & 0 & 0 & 0 & 0 & 0 \\
\hline 4. & Punching & 0 & 0 & 0 & o & 0 & O \\
\hline 5. & Hitting on the head & 0 & 0 & 0 & 0 & 0 & 0 \\
\hline 6. & Clinking heads of two students & 0 & 0 & 0 & o & 0 & 0 \\
\hline 7. & Hitting the head of the students against the wall or desk & 0 & 0 & 0 & o & 0 & O \\
\hline 8. & Kicking & 0 & 0 & 0 & 0 & 0 & 0 \\
\hline 9. & Hitting with an object such as stick, ruler etc. & 0 & 0 & 0 & o & o & 0 \\
\hline 10. & Throwing some objects to students & 0 & 0 & 0 & 0 & 0 & 0 \\
\hline 11. & Making student to stand on one foot in the classroom & 0 & 0 & 0 & o & 0 & o \\
\hline 12. & $\begin{array}{l}\text { Making fun of physical characteristics such as height, weight, } \\
\text { dentition, color of hair, color of skin etc. }\end{array}$ & 0 & 0 & 0 & 0 & 0 & 0 \\
\hline 13. & Making fun about personal appearance (clothes, glasses, etc.) & 0 & 0 & 0 & o & o & O \\
\hline 14. & Making fun about accents, dialect or style of pronunciation & 0 & 0 & 0 & o & o & O \\
\hline 15. & Making fun about first name or surname & 0 & 0 & 0 & o & 0 & O \\
\hline 16. & Calling insulting names, nicknames & 0 & 0 & 0 & o & $\mathbf{0}$ & 0 \\
\hline 17. & Scolding the whole class or a group that you are in & 0 & 0 & 0 & o & 0 & O \\
\hline 18. & Calling rude words (stupid, silly, idiot, meek etc.) & 0 & 0 & 0 & o & 0 & 0 \\
\hline
\end{tabular}




\begin{tabular}{|c|c|c|c|c|c|c|c|}
\hline 19. & Continuously searching to find defects & 0 & o & o & o & 0 & O \\
\hline 20. & Accusing with no reason & 0 & o & 0 & 0 & 0 & 0 \\
\hline 21. & To regard as inferior & 0 & 0 & 0 & 0 & 0 & 0 \\
\hline 22. & Threatening to give low marks or to fail the class & 0 & 0 & 0 & 0 & 0 & 0 \\
\hline 23. & $\begin{array}{l}\text { To embarrass in front of the other students (making fun of } \\
\text { homework or exam papers) }\end{array}$ & 0 & o & o & 0 & 0 & 0 \\
\hline 24. & $\begin{array}{l}\text { Ignoring not giving permission to talk, not responding to } \\
\text { questions etc. }\end{array}$ & 0 & 0 & 0 & 0 & 0 & 0 \\
\hline 25. & Giving extra homework as punishment & 0 & 0 & 0 & 0 & 0 & 0 \\
\hline 26. & $\begin{array}{l}\text { Restrict freedom such as not allowing to go out the class during } \\
\text { break times }\end{array}$ & 0 & 0 & 0 & 0 & 0 & 0 \\
\hline 27. & $\begin{array}{l}\text { Making negative speech or comments about some students to } \\
\text { influence the others }\end{array}$ & 0 & 0 & 0 & 0 & 0 & 0 \\
\hline 28. & Unjustly complaining to the administration & 0 & o & 운 & 0 & 0 & O \\
\hline 29. & Disclosing personal or private information & 0 & o & o & 0 & 0 & O \\
\hline 30. & $\begin{array}{l}\text { Tearing personal belongings such as books, notebooks, } \\
\text { homework or drawings }\end{array}$ & 0 & 0 & o & 0 & 0 & 0 \\
\hline 31. & Making jokes of sexual nature & 0 & o & o & 0 & 0 & o \\
\hline 32. & Forcing to talk about sexuality & 0 & 0 & 0 & o & 0 & 0 \\
\hline 33. & Calling him/her with words having sexual connotations & 0 & o & o & o & 0 & o \\
\hline 34. & Sexual movements (hand, arm, eye movement etc.) & 0 & o & o & o & 0 & o \\
\hline 35. & Sexual touching & 0 & o & o & 0 & 0 & 0 \\
\hline 36. & Creating and spreading rumors of sexual nature & 0 & O & o & o & 0 & o \\
\hline
\end{tabular}

